\title{
Preservation of hamster oocytes to assay the fertilizing capacity of human spermatozoa
}

\author{
P. Quinn*†, C. Barros* $\ddagger$ and D. G. Whittingham* $\S$ \\ ${ }^{*}$ M.R.C. Mammalian Development Unit, Wolfson House (University College London), \\ 4 Stephenson Way, London NWI 2HE, U.K., †Department of Biological Sciences, \\ University of Newcastle, New South Wales 2308, Austratia; and $\ddagger$ Department de Fisiologia y \\ Embriologia, Universidad Catolica de Chile, Santiago, Chile
}

\begin{abstract}
Summary. Between 70 and $80 \%$ of zona-intact hamster ova survived freezing after slow cooling $\left(\sim 0.3^{\circ} \mathrm{C} / \mathrm{min}\right)$ to $-80^{\circ} \mathrm{C}$ in Medium PB1 containing 1.5 or 2.0 M-DMSO before transfer to $-196^{\circ} \mathrm{C}$. After slow warming $\left(\sim 8^{\circ} \mathrm{C} / \mathrm{min}\right)$, there was no difference in survival if the DMSO was diluted out by a slow stepwise or a rapid single addition of medium. When slow cooling was terminated at $-40^{\circ} \mathrm{C}$ by direct transfer to $-196^{\circ} \mathrm{C}$, up to $75 \%$ of the ova survived rapid warming $\left(\sim 500^{\circ} \mathrm{C} / \mathrm{min}\right)$ and rapid dilution if the medium contained $2.0 \mathrm{M}$-DMSO. The survival rates were calculated on the basis of the number of thawed ova which retained their normal morphological appearance after a $1 \mathrm{~h}$ incubation before removal of the zona pellucida with trypsin. All of these ova were penetrated after incubation with mouse spermatozoa, indicating that the freezing procedure per se does not adversely affect the penetration of frozen-thawed hamster ova by heterologous spermatozoa.

There was no difference in the penetration rate of human spermatozoa into frozen $(34 \%)$ or fresh $(42 \%)$ oocytes when a Hepes-buffered Tyrode solution containing $30 \mathrm{mg} \mathrm{BSA} / \mathrm{ml}$ and $2.0 \mathrm{M}$-DMSO was used as the freezing medium. However, fewer ova frozen in Medium PB1 containing $4 \mathrm{mg} \mathrm{BSA} / \mathrm{ml}$ and 2.0 M-DMSO were penetrated by human spermatozoa (18\%) compared with freshly collected ova (38\%). Zona-free ova did not survive the freezing procedure as well as zona-intact ova.

The survival of hamster oocytes stored at $-196^{\circ} \mathrm{C}$ offers a convenient means of supplying and transporting these ova for the assessment of the fertilizing capacity of human and other heterologous spermatozoa.
\end{abstract}

\section{Introduction}

Yanagimachi, Yanagimachi \& Rogers (1976) presented evidence that acrosome-reacted human spermatozoa could fuse with zona-free hamster oocytes in vitro. In subsequent studies, Barros, Gonzalez, Herrera \& Bustos-Obregon $(1978,1979)$ and Rogers et al. (1979) showed that the interaction of human spermatozoa with zona-free hamster oocytes was a valuable tool to discriminate between samples of semen from fertile and suspected infertile men. So far, the fusion of human spermatozoa with oocytes of any other mammalian species has not been demonstrated. Quinn (1979) was unable to obtain penetration of human spermatozoa into

+ Present address: Department of Obstetrics and Gynaecology, Queen Elizabeth Hospital, Woodville, South Australia 5011.

§ Present address: M.R.C. Laboratory Animals Centre, Woodmansterne Road, Carshalton, Surrey, U.K. 
zona-free mouse and rat oocytes. Therefore, the provision of hamster oocytes appears to be of paramount importance in places where this species is not yet available, e.g. Australia, and for routine use in infertility clinics where a ready supply of animals may be unavailable.

Hamster oocytes have been stored at $-75^{\circ} \mathrm{C}$ by Parkening \& Chang (1977) and at $-50^{\circ} \mathrm{C}$ by Fleming, Yanagimachi \& Yanagimachi (1979), with good recovery rates and high percentages of fertilization in vitro. However, for prolonged storage of large numbers of oocytes and for convenient transport in liquid nitrogen, it would be necessary to store them at $-196^{\circ} \mathrm{C}$, a temperature at which only photophysical reactions take place (Whittingham, 1980). The present study was undertaken to define the optimal conditions for preserving hamster oocytes at $-196^{\circ} \mathrm{C}$ in order to assess the fertilizing capacity of human and other heterologous spermatozoa.

\section{Media}

\section{Materials and Methods}

The composition of the various media used is shown in Table 1. The Hepes-buffered Tyrode's (HT6) medium used for freezing oocytes contained a purified bovine serum albumin (BSA) preparation (Quinn \& Stanger, 1980) at $30 \mathrm{mg} / \mathrm{ml}$. This purified BSA was also used at 30 $\mathrm{mg} / \mathrm{ml}$ in the modified Tyrode's medium (T6) for the capacitation of human spermatozoa and their incubation with zona-free hamster oocytes. Untreated BSA (Sigma, Fraction V) was used at a concentration of $15 \mathrm{mg} / \mathrm{ml}$ in $\mathrm{T} 6$ medium for the capacitation of mouse spermatozoa and their incubation with hamster oocytes. Both $\mathrm{T} 6$ media had their $\mathrm{pH}$ adjusted to 7.5-7.6 with 1 $\mathrm{N}-\mathrm{NaOH}$ after the addition of BSA. Medium M2 containing hyaluronidase $(300 \mathrm{U} / \mathrm{ml}$; Type II, Sigma) was frozen in $1 \mathrm{ml}$ aliquots at $-20^{\circ} \mathrm{C}$ until used. The PB 1 medium containing 1.5 or 2.0 M-dimethyl sulphoxide (DMSO; BDH Chemicals) was used as the freezing medium in Exps 1 and 2.

Table 1. Composition of media

\begin{tabular}{|c|c|c|c|c|}
\hline Component & Medium M2 & Medium PB1 & Medium HT6 & Medium T6 \\
\hline $\mathrm{NaCl}(\mathrm{mm})$ & 94.7 & 136.9 & 99.4 & 99.4 \\
\hline $\mathrm{KCl}(\mathrm{mM})$ & $4 \cdot 78$ & 2.68 & 1.42 & 1.42 \\
\hline $\mathrm{MgSO}_{4} \cdot 7 \mathrm{H}_{2} \mathrm{O}(\mathrm{mm})$ & $1 \cdot 19$ & - & - & - \\
\hline $\mathrm{MgCl}_{2} \cdot 6 \mathrm{H}_{2} \mathrm{O}(\mathrm{mM})$ & - & 0.49 & 0.47 & 0.47 \\
\hline $\mathrm{KH}_{2} \mathrm{PO}_{4}(\mathrm{mM})$ & $1 \cdot 19$ & 1.47 & - & - \\
\hline $\mathrm{Na}_{2} \mathrm{HPO}_{4} \cdot 12 \mathrm{H}_{2} \mathrm{O}(\mathrm{mM})$ & - & 8.04 & 0.36 & 0.36 \\
\hline $\mathrm{CaCl}_{2} \cdot 2 \mathrm{H}_{2} \mathrm{O}(\mathrm{mM})$ & 1.71 & 0.90 & 1.78 & $1 \cdot 78$ \\
\hline $\mathrm{NaHCO}_{3}(\mathrm{mM})$ & 4.0 & - & 4.0 & $25 \cdot 0$ \\
\hline $\mathrm{Hepes}^{*}(\mathrm{mM})$ & $21 \cdot 0$ & - & $21 \cdot 0$ & - \\
\hline $\mathrm{Na}$ lactate $\uparrow(\mathrm{mM})$ & $23 \cdot 3$ & - & 24.9 & $24 \cdot 9$ \\
\hline Na pyruvate $(\mathrm{mM})$ & 0.33 & 0.33 & 0.47 & 0.47 \\
\hline Glucose (mM) & $5 \cdot 56$ & 5.56 & 5.56 & $5 \cdot 56$ \\
\hline Penicillin (U/ml) & 100 & 100 & 100 & 100 \\
\hline $\begin{array}{l}\text { Streptomycin sulphate } \\
\quad(\mu \mathrm{g} / \mathrm{ml})\end{array}$ & 50 & - & 50 & 50 \\
\hline Phenol Red $(\%, w / v)$ & 0.001 & 0.001 & 0.001 & 0.001 \\
\hline BSA $(\mathrm{mg} / \mathrm{ml})$ & 4 & 4 & $30 \S$ & $15-30 \S$ \\
\hline
\end{tabular}

* Calbiochem-Ultrol. Stock solution adjusted to $\mathrm{pH} 7.4-7.5$ with $1 \mathrm{~N}-\mathrm{NaOH}$.

† Sigma grade DLV, $60 \%$ syrup.

$\ddagger$ Sigma Type II.

$\S$ See 'Materials and Methods'.

\section{Collection of oocytes}

Adult female golden hamsters (Wrights, Essex) were induced to superovulate by an intraperitoneal injection (i.p.) of 25 i.u. PMSG (Folligon: Intervet) on the day of the 
post-oestrous discharge followed $56 \mathrm{~h}$ later by an i.p. injection of 25 i.u. hCG (Chorulon: Intervet) (Yanagimachi, 1969). The females were killed 16-17 h after the hCG injection. Ovulated oocytes recovered from the ampullar region of the oviduct were incubated in Medium M2 (Table 1) containing hyaluronidase $(300 \mathrm{U} / \mathrm{ml})$ to free them of cumulus cells.

\section{Freezing}

Cumulus-free oocytes were washed three times in the medium to be used for freezing, placed in $0.15 \mathrm{ml}$ of the freezing medium in $12 \times 75 \mathrm{~mm}$ glass culture tubes and kept on ice for $10 \mathrm{~min}$. Then, an additional $0.15 \mathrm{ml}$ of a double-strength DMSO solution in freezing medium at $0^{\circ} \mathrm{C}$ was added to give a final concentration of 1.5 or $2.0 \mathrm{M}$-DMSO. The tubes were left on ice for a further $5 \mathrm{~min}$ before being transferred to a $-6^{\circ} \mathrm{C}$ bath. After $1 \mathrm{~min}$, ice formation was induced by touching the outside of the tubes just above the level of the medium with a pair of forceps precooled in liquid $\mathrm{N}_{2}$ and giving each tube a sharp tap. After ice formation, the tubes were left in the $-6^{\circ} \mathrm{C}$ bath for $2 \mathrm{~min}$ to attain the seeding bath temperature and then transferred to a cooling bath with a cooling rate of $\sim 0.3^{\circ} \mathrm{C} / \mathrm{min}$ (Whittingham, Wood, Farrant, Lee \& Halsey, 1979). Some samples were transferred to liquid $\mathrm{N}_{2}$ upon reaching $-40^{\circ} \mathrm{C}$ and others were transferred upon reaching $-80^{\circ} \mathrm{C}$.

\section{Thawing}

Oocytes frozen to $-40^{\circ} \mathrm{C}$ before transfer to liquid $\mathrm{N}_{2}$ were rapidly thawed at $\sim 500^{\circ} \mathrm{C} / \mathrm{min}$ by vigorous agitation in a $40^{\circ} \mathrm{C}$ bath until all the ice had disappeared whereas those transferred at $-80^{\circ} \mathrm{C}$ were slowly warmed at $\sim 8^{\circ} \mathrm{C} / \mathrm{min}$ by placing the freezing tubes in a $200 \times 38 \mathrm{~mm}$ boiling tube which had been prechilled in liquid $\mathrm{N}_{2}$ and then left at room temperature (Whittingham et al., 1979). After the samples had thawed, they were left at room temperature for 5 min before dilution of the DMSO.

\section{Dilution of DMSO}

The thawed samples were diluted at room temperature by (a) stepwise addition, at 1-min intervals, of $0.3,0.3$ and $0.6 \mathrm{ml}$ freezing medium at room temperature, or (b) the single addition of $1 \mathrm{ml}$ medium. The diluted contents of each freezing tube were emptied into an embryological watchglass and the tube rinsed twice with $1 \mathrm{ml}$ medium.

\section{Removal of zona pellucida}

After recovery, ova appearing morphologically normal were placed in droplets of fertilization medium T6 (Table 1) under paraffin oil in a $5 \% \mathrm{CO}$, in air incubator at $37^{\circ} \mathrm{C}$ for $1 \mathrm{~h}$. The criteria for normal morphology of ova included the fact that the vitellus was light, non-granular and translucent with a distinct periphery. Ova which had a deformed or cracked zona pellucida but a vitellus with the above characteristics were also regarded as being normal and capable of being fertilized. At the end of the $1 \mathrm{~h}$ incubation, the ova which still appeared normal were placed in medium containing $0.1 \%(\mathrm{w} / \mathrm{v})$ trypsin (bovine pancreatic, $3000 \mathrm{U} / \mathrm{mg}$, Sigma) to remove the zonae pellucidae, washed twice in fresh medium and placed with capacitated mouse or human spermatozoa. Freshly collected hamster oocytes had their zonae removed in a similar fashion after being freed of cumulus cells using hyaluronidase $(300 \mathrm{U} / \mathrm{ml}$ in Medium M2).

\section{Fertilization assays}

Mouse spermatozoa were collected from mature $(\mathrm{C} 57 \mathrm{BL} \times \mathrm{CBA}) \mathrm{F}_{1}$ males and at a final concentration of $1-2 \times 10^{5} / \mathrm{ml}$ were preincubated in $0.5 \mathrm{ml}$ of fertilization medium (T6 with 15 
mg untreated $\mathrm{BSA} / \mathrm{ml}$ ) under oil in $5 \% \mathrm{CO}_{2}$ in air at $37^{\circ} \mathrm{C}$ for $2 \mathrm{~h}$ to effect capacitation (Quinn, 1979). Human spermatozoa were prepared from the liquefied ejaculates of healthy donors of proven fertility by an overlay technique (Quinn \& Stanger, 1980). The sample was centrifuged once at $600 \mathrm{~g}$ for $5 \mathrm{~min}$ to remove any residual seminal plasma components. The spermatozoa were resuspended in $0.125 \mathrm{ml}$ fertilization medium (final concentration $10^{7}$ spermatozoa $/ \mathrm{ml}$ ) under paraffin oil and preincubated for $17 \mathrm{~h}$ at $37^{\circ} \mathrm{C}$ in $5 \% \mathrm{CO}_{2}$ in air to effect capacitation. Two donors, both of whom had spermatozoa which penetrated $30-56 \%$ of freshly collected zona-free hamster ova were used in all experiments. For each replicate of an experiment, the spermatozoa from only one of these donors was used for all treatments.

The zona-free hamster oocytes were incubated with the capacitated spermatozoa for 3-6 h, removed and washed thoroughly through two changes of fresh medium to remove loosely adherent spermatozoa and then fixed and stained with orcein (Toyoda \& Chang, 1974). The ova were assessed using phase-contrast and bright-field microscopy and only considered to have been penetrated by spermatozoa when they contained a decondensing sperm head or male pronucleus with accompanying sperm tail.

\section{Experiment 1}

\section{Results}

Table 2 shows the survival of hamster ova stored at $-196^{\circ} \mathrm{C}$ in Medium PB1 after removal of the zona pellucida upon thawing. Between 70 and $80 \%$ of the ova survived slow cooling to $-80^{\circ} \mathrm{C}$ in medium containing 1.5 or $2.0 \mathrm{M}$-DMSO. After slow warming, there was no difference in survival if the DMSO was diluted out by a stepwise addition of Medium PB1 at $1 \mathrm{~min}$ intervals or a single addition of $1 \mathrm{ml}$ medium. When slow cooling was terminated at $-40^{\circ} \mathrm{C}$ by direct transfer to liquid $\mathrm{N}_{2}$, about $75 \%$ of the ova survived rapid warming and rapid dilution if the medium contained $2.0 \mathrm{M}$-DMSO. Survival was reduced to $50-65 \%$ in the remaining treatments in this experiment. Differences between treatments for survival of the frozen-thawed ova at the end of the $1 \mathrm{~h}$ incubation before removal of their zonae pellucidae were assessed by chi-squared analysis. There was no significant difference between the two dilution methods (stepwise and rapid) and although an average of $73 \%$ of the ova survived when the freezing medium contained $2.0 \mathrm{M}$-DMSO, this was not significantly greater than the value of $66 \%$ obtained when 1.5 M-DMSO was used $\left(\chi_{1}^{2},=2.40, P>0.1\right)$. Significantly more ova survived when slow cooling was terminated at $-80^{\circ} \mathrm{C}$ instead of $-40^{\circ} \mathrm{C}$ (75 compared with $\left.64 \%, \chi_{1}{ }^{2}=5.42, P<0.05\right)$.

Table 2. Survival of hamster ova after storage at $-196^{\circ} \mathrm{C}$ in $\mathrm{PB} 1$ containing DMSO

\begin{tabular}{|c|c|c|c|c|c|}
\hline \multirow{3}{*}{$\begin{array}{l}\text { Temp. when transferred } \\
\text { to liquid } \mathrm{N}_{2} \\
\left({ }^{\circ} \mathrm{C}\right)\end{array}$} & \multirow{2}{*}{\multicolumn{2}{|c|}{ DMSO }} & \multicolumn{3}{|c|}{ No. of ova } \\
\hline & & & & & Surviving \\
\hline & Conc. (M) & Dilution & Frozen & Thawed & (\%) \\
\hline-40 & 1.5 & Stepwise* & 51 & 42 & $28(67)$ \\
\hline-40 & 1.5 & Rapid $\dagger$ & 50 & 46 & $23(50)$ \\
\hline-40 & 2.0 & Stepwise & 46 & 40 & $25(63)$ \\
\hline-40 & $2 \cdot 0$ & Rapid & 46 & 42 & $32(76)$ \\
\hline-80 & 1.5 & Stepwise & 55 & 54 & $37(69)$ \\
\hline-80 & 1.5 & Rapid & 42 & 39 & $31(79)$ \\
\hline-80 & $2 \cdot 0$ & Stepwise & 45 & 44 & $35(80)$ \\
\hline-80 & 2.0 & Rapid & 46 & 43 & $32(74)$ \\
\hline
\end{tabular}

Values are for 4 replicates of each treatment.

* Stepwise addition of $0.3,0.3$ and $0.6 \mathrm{ml}$ Medium PB 1 at 1 -min intervals.

$\dagger$ Single addition of $1.0 \mathrm{ml}$ Medium PB 1 . 
In this experiment, all of the ova which survived the storage period, (5-98 days) were penetrated after incubation for $4 \mathrm{~h}$ with capacitated mouse spermatozoa, indicating that the freezing procedure did not prevent penetration of ova by heterologous spermatozoa. The concentration of mouse spermatozoa had to be $\leqslant 2 \times 10^{5} / \mathrm{ml}$ or it was difficult to distinguish the many dispersing sperm nuclei inside the vitellus from sperm heads attached to the overlying surface of the oocyte.

In some ova the sperm nuclei were difficult to see as they were fully dispersed and only the midpiece and sperm tail were visible on the surface of the oocytes. The progress of decondensation of the mouse sperm nuclei was slower in the hamster oocyte than it is in mouse oocytes in which fully formed male pronuclei are usually visible after incubation for $4 \mathrm{~h}$ (P. Quinn \& D. G. Whittingham, unpublished observations). These were never observed in the hamster oocytes in this study.

\section{Experiment 2}

The DMSO concentration which had given the higher survival rate in Exp. 1 (2.0 M-DMSO) and the simpler rapid dilution procedure were chosen and oocytes with and without their zonae pellucidae were slowly cooled to -40 or $-80^{\circ} \mathrm{C}$ before transfer to liquid $\mathrm{N}_{2}$. The survival of zona-free ova frozen to $-196^{\circ} \mathrm{C}$ was considerably reduced compared to that of their zona-intact counterparts (Table $3 ; \chi_{1}{ }^{2}=71.9, P<0.001$ ). The survival of the zona-intact ova in this experiment was similar to that in Exp. 1 but the number of ova penetrated by capacitated human spermatozoa was only about half of that obtained with unfrozen control ova (Table 3).

Table 3. Penetration of hamster ova by human spermatozoa after storage at $-196^{\circ} \mathrm{C}$ in Medium PB 1 containing 2.0 M-DMSO

\begin{tabular}{ccccccc}
\hline \multicolumn{2}{c}{ Treatment } & & \multicolumn{4}{c}{ No. of ova } \\
\cline { 5 - 7 } $\begin{array}{c}\text { Temp. when transferred } \\
\text { to liquid } \mathrm{N}_{2}\left({ }^{\circ} \mathrm{C}\right)\end{array}$ & $\begin{array}{c}\text { Zona } \\
\text { pellucida }\end{array}$ & & Frozen & Thawed & $\begin{array}{c}\text { Surviving } \\
(\%)\end{array}$ & $\begin{array}{c}\text { Penetrated } \\
(\%)^{*}\end{array}$ \\
\hline-40 & Present & & 94 & 88 & $58(66)$ & $10(17)$ \\
-40 & Absent & & 61 & 56 & $9(16)$ & $1(11)$ \\
-80 & Present & & 95 & 87 & $66(76)$ & $11(18) \dagger$ \\
-80 & Absent & & 66 & 61 & $28(46)$ & $5(18)$ \\
Non-frozen controls & & & & 69 & $26(38)$ \\
\hline
\end{tabular}

Values are for 2-3 replicates of each treatment. All treatments had a rapid dilution of DMSO after thawing.

* Of ova surviving.

$\dagger 5$ surviving ova lost.

\section{Experiment 3}

Zona-intact ova were frozen in Medium HT6 (see Table 1). The DMSO (2.0 M) was diluted rapidly after thawing at room temperature. High survival rates after storage were obtained whether slow cooling was terminated at -40 or $-80^{\circ} \mathrm{C}$ before transfer to liquid $\mathrm{N}_{2}$ (Table 4). The survival of ova transferred to liquid $\mathrm{N}_{2}$ when slow cooling was terminated at $-80^{\circ} \mathrm{C}$ was significantly $\left(\chi_{1}{ }^{2}=5.24, P<0.05\right)$ greater than that of the ova transferred at $-40^{\circ} \mathrm{C}$. There was no significant $\left(\chi_{1}{ }^{2}=2.74, P>0.05\right.$ and $\chi_{1}{ }^{2}=0.1, P>0.75$ for the -40 and $-80^{\circ} \mathrm{C}$ treatments, respectively) difference in the penetration rates of human spermatozoa between the frozen and fresh ova. The decondensation of the sperm nuclei after $6 \mathrm{~h}$ incubation was slower in frozen than in fresh ova. In fresh ova, the sperm nucleus had developed to the pronuclear stage 
Table 4. Penetration of hamster ova by human spermatozoa after storage at $-196^{\circ} \mathrm{C}$ of zona-intact ova in Medium HT6 containing $30 \mathrm{mg} \mathrm{BSA} / \mathrm{ml}$ and 2.0 M-DMSO

\begin{tabular}{|c|c|c|c|c|}
\hline \multirow[b]{2}{*}{$\begin{array}{l}\text { Temp. when transferred } \\
\text { to liquid } \mathrm{N}_{2}\left({ }^{\circ} \mathrm{C}\right)\end{array}$} & \multicolumn{4}{|c|}{ No. of ova } \\
\hline & Frozen & Thawed & $\begin{array}{l}\text { Surviving } \\
(\%)\end{array}$ & $\begin{array}{l}\text { Penetrated } \\
(\%)^{*}\end{array}$ \\
\hline $\begin{array}{l}-40 \\
-80\end{array}$ & $\begin{array}{l}59 \\
59\end{array}$ & $\begin{array}{l}52 \\
54\end{array}$ & $\begin{array}{l}37(71) \\
48(89)\end{array}$ & $\begin{array}{c}9(24) \\
15(45) \dagger\end{array}$ \\
\hline Non-frozen controls & & & 43 & $18(42)$ \\
\hline
\end{tabular}

Table 5. Comparison of human sperm penetration into freshly collected zona-free hamster ova and after storage at $-196^{\circ} \mathrm{C}$

\begin{tabular}{llc}
\hline & $\begin{array}{c}\text { No. of ova penetrated/ } \\
\text { total no. tested } \\
\text { T\%) }\end{array}$ & $\chi_{1}{ }^{2}$ \\
\hline Storage in Medium PB1 & $21 / 119(18)$ & $8.85(P<0.01)$ \\
Freshly collected & $26 / 69(38)$ & \\
Storage in Medium HT6 & $24 / 70(34)$ & $0.65(P>0.5)$ \\
Freshly collected & $18 / 43(42)$ & \\
\hline
\end{tabular}

Values are for 2-3 replicates of each treatment taken from Tables 3 and 4.

in 12 out of 18 ova penetrated, but with frozen-thawed ova only 2 out of 24 penetrated ova contained sperm nuclei at the equivalent pronuclear stage.

When the penetration rates of human spermatozoa into zona-free hamster oocytes which were frozen in Medium PB1 or HT6 with 2.0 M-DMSO were compared (Table 5), there was a difference for the two media.

\section{Discussion}

This study shows that hamster oocytes can be frozen to $-196^{\circ} \mathrm{C}$, stored at this temperature for up to 98 days and then thawed, resulting in a good recovery of ova which can be readily penetrated by heterologous (mouse and human) spermatozoa. Many capacitated mouse spermatozoa penetrated the frozen-thawed zona-free hamster oocytes but only proceeded to the swollen sperm head stage. Development did not progress to fully formed male pronuclei as it does in mouse oocytes over a similar period. Hanada \& Chang (1972) also reported that the transformation of mouse sperm heads into male pronuclei was delayed in the hamster vitellus. This does not seem to be due to an excessive number of sperm heads present in the egg cytoplasm because a concentration range of $10^{6}-10^{3}$ mouse spermatozoa $/ \mathrm{ml}$ in the fertilization medium resulted in 1.5-11.2 penetrating spermatozoa per freshly collected hamster ovum; these spermatozoa had all proceeded only as far as the swollen sperm head stage over a $4 \mathrm{~h}$ incubation 
period irrespective of the number of spermatozoa present in the ovum (P. Quinn \& D. G. Whittingham, unpublished observations). In mouse ova, the rate of decondensation of penetrating mouse spermatozoa is reported to be inversely related to the number of penetrating spermatozoa per ovum (Witkowska, 1981). Thus, mouse and hamster oocytes appear to differ in their ability to decondense mouse sperm heads. Whether this is due to a species difference in the activity of the enzyme systems responsible for sperm head decondensation or to the heterologous combination of egg cytoplasm and sperm head is unknown. Our results lend support to the latter explanation since capacitated human spermatozoa readily decondensed into fully formed male pronuclei after penetrating the hamster vitellus. The rate of decondensation of the human spermatozoa was faster in freshly collected hamster oocytes than in frozen-thawed oocytes. The cryopreservation of oocytes might affect the level of activity of the mechanism which brings about sperm head decondensation and male pronucleus formation (the 'male pronucleus growth factor': Thibault, Gerard \& Menezo, 1975). Alternatively, the slower rate of decondensation of the human sperm nucleus might result from an initial delay in sperm penetration. Further studies are required to determine the exact cause of the retardation in frozen-thawed hamster oocytes. Meanwhile, when frozen-thawed hamster oocytes are used to assess the penetration of human spermatozoa from suspected infertile men, direct comparisons must be made simultaneously with fertile human semen.

The survival of hamster oocytes frozen to $-196^{\circ} \mathrm{C}$ in Medium PB 1 was similar to that reported previously for mouse embryos treated with the same freezing and thawing regimens (Whittingham et al., 1979). It was also similar to that for hamster oocytes stored at $-50^{\circ} \mathrm{C}$ (Fleming et al., 1979) and $-75^{\circ} \mathrm{C}$ (Parkening \& Chang, 1977). Oocytes and embryos stored at about $-50^{\circ} \mathrm{C}$ are probably in an extremely unstable supercooled state since the temperature at which intracellular ice nucleation takes place in slowly cooled embryos is between -40 and $-60^{\circ} \mathrm{C}$ (Leibo, 1977). Observations with a low temperature microscope indicate that the formation of intracellular ice is not damaging per se but extended periods (during slow thawing) at high sub-zero temperatures once it has formed are lethal (Rall, Reid \& Farrant, 1980). Therefore, it is more satisfactory and convenient to store hamster oocytes in liquid $\mathrm{N}_{2}\left(-196^{\circ} \mathrm{C}\right)$ for transport or long-term storage to ensure that any variation in the storage temperature has no detrimental effect on the survival of the ova. Whittingham et al. (1979) found that the rate of warming necessary to obtain optimal survival of mouse embryos is dependent on the temperature at which slow cooling is ended before immersion in liquid $\mathrm{N}_{2}$. Our results show that hamster oocytes behave in a similar fashion. The hamster oocytes frozen in Medium HT6 survived better when slowly warmed after slow cooling to $-80^{\circ} \mathrm{C}$ before immersion in liquid $\mathrm{N}_{2}$ than when they were rapidly warmed after slow cooling terminating at $-40^{\circ} \mathrm{C}$ before transfer to liquid $\mathrm{N}_{2}$ (Table 4). In contrast, mouse embryos frozen in Medium PB1 show no difference in survival if warmed at the correct rates whether the slow cooling is terminated at -40 or $-80^{\circ} \mathrm{C}$ (Whittingham et al., 1979).

The reduced survival of hamster oocytes frozen without their zonae pellucidae contrasts with the high survival rates obtained by Fleming et al. (1979). This may result from differences in the final storage temperature $\left(-196^{\circ} \mathrm{C}\right.$ in the present study, $-50^{\circ} \mathrm{C}$ in the study of Fleming et al., 1979). We also found that hamster oocytes frozen in a phosphate-buffered medium containing 4 mg BSA/ml (Medium PB1) were penetrated less effectively by human spermatozoa than after the oocytes were frozen in a Hepes-buffered medium containing $30 \mathrm{mg} \mathrm{BSA} / \mathrm{ml}$ (Medium HT6). Fleming et al. (1979) obtained optimal survival rates of frozen hamster oocytes with medium containing a high protein concentration ( $10 \%$ fetal calf serum). It is known that phosphatebuffered medium is detrimental to the survival of mouse embryos at $37^{\circ} \mathrm{C}$ (Quinn \& Wales, 1973). The superior survival rates of the hamster oocytes stored in Medium HT6 rather than Medium PB1 could be due to the differences in protein concentration and/or buffering system. Whatever the reasons, our results show that it is feasible to store hamster oocytes at $-196^{\circ} \mathrm{C}$ using a straightforward procedure and that the frozen-thawed oocytes are readily penetrated by 
heterologous spermatozoa. The recommended procedure is to cool zona intact ova slowly $\left(\sim 0.3^{\circ} \mathrm{C} / \mathrm{min}\right)$ in Hepes-buffered Tyrode medium containing $30 \mathrm{mg} \mathrm{BSA} / \mathrm{ml}$ and $2.0 \mathrm{M}$-DMSO to $-80^{\circ} \mathrm{C}$ and then transfer them to liquid $\mathrm{N}_{2}$. The frozen ova should be slowly thawed at $\sim 8^{\circ} \mathrm{C} / \mathrm{min}$ and the DMSO can be diluted out at room temperature by a single addition of $1 \mathrm{ml}$ DMSO-free medium to $0.3 \mathrm{ml}$ of the freezing medium. The ova are then washed twice in fresh medium and incubated for $1 \mathrm{~h}$ before the zona pellucida is removed with trypsin. This method provides a convenient way of supplying and transporting hamster oocytes for the assessment of the fertilizing capacity of human and other mammalian spermatozoa.

P.Q. gratefully acknowledges the receipt of a Royal Society Commonwealth Bursary and C.B. the support of the Catholic University of Chile and of the British Council.

\section{References}

Barros, C., Gonzalez, J., Herrera, E. \& Bustos-Obregon, E. (1978) Fertilizing capacity of human spermatozoa evaluated by actual penetration of foreign eggs. Contraception 17, 87-92.

Barros, C., Gonzalez, J., Herrera, E. \& Bustos-Obregon, E. (1979) Human sperm penetration into zona-free hamster oocytes as a test to evaluate the sperm fertilizing ability. Andrologia 11, 197-210.

Fleming, A.D., Yanagimachi, R. \& Yanagimachi, H. (1979) Fertilizability of cryopreserved zona-free hamster ova. Gamete Res. 2, 357-366.

Hanada, A. \& Chang, M.C. (1972) Penetration of zona-free eggs by spermatozoa of different species. Biol. Reprod. 6, 300-309.

Leibo, S.P. (1977) Fundamental cryobiology of mouse ova and embryos. In The Freezing of Mammalian Embryos (Ciba Fndn Symp. No. 52, new series), pp. 69-92. Eds K. Elliott \& J. Whelan. Elsevier/North Holland, Amsterdam.

Parkening, T.A. \& Chang, M.C. (1977) Effects of cooling rates and maturity of the animal on the recovery and fertilization of frozen-thawed rodent eggs. Biol. Reprod. 17, 527-531.

Quinn, P. (1979) Failure of human spermatozoa to penetrate zona free mouse and rat ova in vitro. $J$. exp. Zool. 210, 497-506.

Quinn, P. \& Stanger, J.D. (1980) Effect of purification of bovine serum albumin on the interaction of human semen with mouse ova in vitro. Biol. Reprod. 22, 134-140.

Quinn, P. \& Wales, R.G. (1973) Growth and metabolism of preimplantation mouse embryos cultured in phosphate-buffered medium. J. Reprod. Fert. 35, 289-300.
Rall, W.F., Reid, D.S. \& Farrant, J. (1980) Innocuous biological freezing during warming. Nature, Lond. 286, 511-514.

Rogers, B.J., van Campen, H., Veno, M., Lambert, H., Bronson, R. \& Hale, R. (1979) Analysis of human spermatozoal fertilizing ability using zona-free ova. Fert. Steril. 32, 664-670.

Thibault, C., Gerard, M. \& Menezo, Y. (1975) Preovulatory and ovulatory mechanisms in oocyte maturation. J. Reprod. Fert. 45, 605-610.

Toyoda, Y. \& Chang, M.C. (1974) Fertilization of rat eggs in vitro by epididymal spermatozoa and the development of eggs following transfer. J. Reprod. Fert. 36, 9-22.

Whittingham, D.G. (1980) Principles of embryo preservation. In Low Temperature Preservation in Medicine and Biology, pp. 65-83. Eds (M. J. Ashwood-Smith \& J. Farrant. Pitman Medical, Tunbridge Wells.

Whittingham, D.G., Wood, M., Farrant, J., Lee, H. \& Halsey, J.A. (1979) Survival of frozen mouse embryos after rapid thawing from $-196^{\circ} \mathrm{C}$. $J$. Reprod. Fert. 56, 11-21.

Witkowska, A. (1981) Pronuclear development and the first cleavage division in polyspermic mouse eggs. $J$. Reprod. Fert. 62, 493-498.

Yanagimachi, R. (1969) In vitro capacitation of hamster spermatozoa by follicular fluid. J. Reprod. Fert. 18, 275-286.

Yanagimachi, R., Yanagimachi, H. \& Rogers, B.J. (1976) The use of zona-free animal ova as a test-system for the assessment of the fertilizing capacity of human spermatozoa. Biol. Reprod. 15, $471-476$. 